\title{
Tsiperifery, the wild pepper from Madagascar, emerging on the international spice market whose exploitation is unchecked:
} current knowledge and future prospects

\author{
H. Razafimandimby1,2,3, A.-G. Benard 1,2, H. Andrianoelisoa ${ }^{1,2}$, J.-M. Leong Pock Tsy ${ }^{2, a}$, G. Touati ${ }^{4}$, A. Levesque ${ }^{5}$ \\ M. Weil5, R. Randrianaivo ${ }^{2,6}$, L. Ramamonjisoa ${ }^{3,7}$, J. Queste ${ }^{2,8}$, S. Aubert ${ }^{2,8}$, J.P. Danflous ${ }^{9}$ and P. Danthu' ${ }^{2,10}$ \\ 1 Département des Recherches Forestières et Piscicoles, FOFIFA, BP 904 Antananarivo, Madagascar \\ 2 DP Forêts et Biodiversité Madagascar, BP 853, Antananarivo, Madagascar \\ 3 Ecole Supérieure des Sciences Agronomiques, Université d'Antananarivo, BP 175 Antananarivo, Madagascar \\ ${ }^{4}$ ISTOM, 32, Boulevard du Port, 95094 Cergy-Pontoise, France \\ ${ }_{5}^{5}$ CIRAD UMR QualiSud, Station Ligne Paradis, 7 Chemin de l'Irat, 97410 Saint-Pierre, BP 180, Réunion, France \\ 6 Département de Recherche Technologiques, Centre National des Recherches Appliquées au Développement Rural, BP 904, \\ Antananarivo, Madagascar \\ 7 Silo National des Graines Forestières, BP 5091, Antananarivo, Madagascar \\ 8 CIRAD, UR Green, Campus de Baillarguet, 34398 Montpellier Cedex 5, France \\ 9 CIRAD, UR Innovation, Station de Bassin Plat, BP 180, 97455 Saint-Pierre Cedex, La Réunion, France \\ ${ }^{10}$ Direction Régionale du CIRAD à Madagascar, BP 853, Antananarivo, Madagascar, et CIRAD DGD-RS, Campus de Lavalette, \\ 34398 Montpellier Cedex 5, France
}

\section{Summary}

Introduction - A new spice on the international market. Tsiperifery is a wild pepper from Madagascar belonging to the genus Piper. This new culinary spice, which is gaining gourmet notoriety due to its unique organoleptic properties and its endemic and exotic origin, is attracting a growing number of actors to harvest and trade it. Scientific challenges - This growing appetite for tsiperifery is making collection of the plant unsustainable and contributing to the degradation of Malagasy forests with the felling of lianas, as well as host trees, and subsequent deforestation. Little is known about the plant, and its trade has developed in the relative absence of any scientific knowledge. There is not even the most basic of information available regarding its geographic distribution, taxonomy, ecology or reproductive mode. Moreover, tsiperifery is regarded simply as black pepper by Malagasy and international regulations. Socio-economic challenge - Poorly paid harvesters. The peppercorns are harvested by pickers from the poorest sector of the local population, earning them a valued income, which is nonetheless derisory compared to the gains made by the other market players. Results and discussion - Lay the bases for a sustainable management of tsiperifery. This finding indicates that scientific backing aimed at reducing uncertainties about the biology, exploitation and transformation of the plant is required to establish the bases for sustainable management of the plant. We suggest supporting the sector in producing sustainably exploited tsiperifery by exploring different innovations, which would include creating a 'label' that guarantees the product's quality through association with its origin and imple-

a Corresponding author: leong@cirad.mg.

\section{Significance of this study}

What is already known on this subject?

- Tsiperifery, wild pepper of Madagascar, is a new spice on the international market. There is hardly any scientific knowledge on this plant.

What are the new findings?

- This paper offers a multidisciplinary review of the existing scientific knowledge and a diagnosis of its exploitation.

What is the expected impact on horticulture?

- Tsiperifery is a credible candidate to large-scale cultivation in Madagascar, once its domestication is mastered.

menting a participative process for domesticating the plant. Conclusion - Advocating for the involvement of all stakeholders. Research has limited impact in a context devoid of economic and political partners, and funders. Without the involvement of major stakeholders, it will be no time before tsiperifery finds its way into the CITES Appendix II.

\section{Keywords}

Madagascar, tsiperifery, wild pepper, Piper spp., sustainable exploitation, non-timber forestry products

\section{Résumé}

Le tsiperifery, le poivre sauvage de Madagascar. Introduction - une épice nouvelle sur le marché international. Le tsiperifery est un poivre sauvage de Madagascar appartenant au genre Piper. Ses qualités 
organoleptiques uniques, son origine endémique et exotique lui ont conféré, récemment, une forte notoriété sur le marché international et ont incité nombre d'acteurs à s'investir dans sa récolte et son commerce. Enjeux scientifiques - En conséquence de cet engouement, la collecte du tsiperifery est un facteur de dégradation des forêts malgaches: abattage des lianes, voire des arbres-support, déforestation. La filière s'est organisée alors que très peu de connaissances scientifiques sont disponibles. Des informations aussi basiques que son aire de répartition, sa taxonomie, son écologie, ses modes de reproduction ne sont pas actuellement disponibles. Par ailleurs, aucune réglementation malgache ne reconnaît le $t s i$ perifery, assimilé au poivre noir. Enjeux socio-économiques - une filière qui rémunère mal les récolteurs locaux. La récolte est réalisée par les populations locales (parmi les plus pauvres de Madagascar) qui en retirent un revenu appréciable, même s'il est faible comparé aux plus-values des autres acteurs de la filière. Résultats et discussion - poser les bases d'une gestion durable du tsiperifery. Ce constat nous suggère une démarche de recherche d'accompagnement visant à réduire les incertitudes sur la biologie de la plante, son exploitation, sa transformation. Nous proposons d'accompagner la filière vers une exploitation durable en explorant différentes innovations: une démarche de création d'un signe de qualité et d'origine et la mise en œuvre d'un processus participatif de domestication. Conclusion - plaidoyer pour l'implication de tous les acteurs. Toutefois, sans appui ou relais politique, des partenaires économiques ou des grands bailleurs, la recherche ne pourra pas éviter que le tsiperifery rejoigne, à brève échéance, l'Annexe II de la CITES.

\section{Mots-clés}

Madagascar, tsiperifery, poivre sauvage, Piper spp., exploitation durable, produits forestiers non-ligneux

\section{A new culinary spice on the international market}

Wild pepper from Madagascar (known locally as tsiperifery, or better still voatsiperifery, the most common commercial tag) has been known to the Malagasy for a long time. It was discovered in 2004 by European celebrity chefs, in particular Olivier Roellinger, a multi-award winning chef, and Gérard Vives, the first to import it to Europe (Couplan, 2009; Vives, 2010). Today, its reputation is well established amongst Europe's restaurateurs, chefs and gourmet spice merchants. All of them rapidly adopted it, ensuring its promotion to the sound of lyrical praise which plays on the product's organoleptic merits, as well as its rare, original, exotic and mysterious nature associated with its endemicity to Madagascar and the difficulties of collecting it (Table 1).

Since 2010, this spice has therefore been the object of particular interest and growing demand on the international market (Touati, 2012). However, whilst tsiperifery is currently riding a gourmet wave as a luxury epicurean product available in the finest delicatessens and associated with delectable dishes served in the most celebrated restaurants, at the other end of the value chain, in the eastern forests of
Madagascar, it is the object of unchecked collection, contributing to the destruction of the ecosystems without providing a fair share of profit to the poorest of the island's population (Touati, 2012).

The sector has been established without any scientific knowledge of the condition of the resource (availability, diversity), of the impact of collection on the resource, on the setting up of operations, or on the modes of post-harvest processing (notably, drying).

A consortium of Malagasy and French researchers overseen by the Dispositif de Recherche et de Formation en Partenariat Forêts et Biodiversité (Platform in partnership for research training forests and biodiversity) is addressing the issue through an interdisciplinary approach to produce the first objective elements regarding tsiperifery. In so doing, they aim to provide the scientific contribution to a sustainable exploitation of this remarkable pepper, taking consideration of the ecological, social and economic imperatives of its harvest, post-harvest processing and trading.

This paper aims to review the knowledge of tsiperifery from scratch and to draft from it a research project which the authors intend to implement. It draws on the earliest scientific elements from the authors' own investigations via preliminary and incomplete student research studies (Touati, 2012; Razafimandimby, 2011; Ratsaraefatrarivo, 2012; Levesque, 2012). A single scientific article has been published to date by Weil et al. (2014), that has been supplemented by information gathered from the internet and, less formally, from the stakeholders in the supply chain.

\section{Abusive exploitation of a traditional forestry product}

\section{Tsiperifery, an old familiar of the Malagasy people}

Whilst the organoleptic properties of tsiperifery are only just finding their way into Western cuisine, it has been well-known to the Malagasy population for its culinary and therapeutic properties, for a very long time.

A survey amongst people living locally to the forest of Tsiazompaniry - a zone with difficult access about $100 \mathrm{~km}$ from the capital - who collect and use tsiperifery traditionally shows that they use the plant for its culinary and medicinal powers. They are also known to attribute the species with esoteric properties (Table 2). This survey assigned a usage-index corresponding to the formula devised by Phillips and Gentry (1993) of $100 \%$, meaning that every informant questioned stated they had already used at least one part of the plant for one of the different uses mentioned in Table 2. This result shows a very good empirical knowledge of the resource and a wide range of uses by local inhabitants, even if the motivations are different.

Different vernacular names for this plant are associated with its various uses. References to its culinary use are very prevalent, as this pepper is used in place of the traditional sakay (chilli in Malagasy): sakaiala (forest chilli) and sakarivonala (forest ginger), sakarivondambo (bushpig ginger). The plant morphology and some of its other cultural uses are also detectable in indigenous names for the plant: $v a$ hibe (great liana), tsimahalatsaka (which wards off rainfall and lightning strikes). And yet, paradoxically, in relation to its main use, the most commonly accepted indigenous name for this spice, as well as its commercial name, is associated with its wound healing properties: tsiperifery, meaning literally 'which makes wounds non-existent'. It is also known as 'voatsiperifery', which means 'fruit of tsiperifery'. 
TABLE 1. Quotes from French and Anglo-Saxon chefs and spice merchants promoting tsiperifery with online prices of tsiperifery.

Gérard Vives (Vives, 2010):

"[...] its aroma bears hints of black pepper and cubeb with woody and earthy notes but with added fresh citrusy and minty notes. Its flavour is very crisp and lingering. It's got a bite which isn't fierce but piercing and tenacious. It's a rare product!"

Bien Manger, http://www.bienmanger.com/ (accessed Feb. 29, 2016):

"Its name comes from 'Voa' which means fruit and 'tsiperifery' which is the name of a plant in Madagascar. This wild-tailed pepper has a complex woody nose, and bitter, spicy aromas. A climber growing up big trees in the tropical rainforest in the South East of the island, it's picked entirely by hand by communities of villagers. [...] It's the ideal accompaniment for grilled red meats, enhanced by its woody aroma! It's marvellous with pork and lamb, foie gras mi-cuit, and even red fruit salad or a moelleux of chocolate."

Price: 87 to $174 € \mathrm{~kg}^{-1}$ according to the packaging.

Epices Roellinger, http://www.epices-roellinger.com/ (accessed Mar. 1, 2016):

"Piper borbonense, of the same family as Piper nigrum, voatsiperifery is a real pepper found in the south of Madagascar. It grows between 10 to 20 metres on creepers in the crown of big trees. Its harvest is so difficult and dangerous that sometimes pickers prefer to cut the trees down... It's a gentle and aromatic pepper, and suits those who don't like the 'meaty' side to Piper nigrum. I like to use it with sea food, steamed vegetables and fruit. It can be eaten whole."

Price: $202 € \mathrm{~kg}^{-1}$.

Les épices rient!, http://www.lesepicesrient.fr/ (accessed Feb. 29, 2016):

"[...] This little peppercorn is full of surprises, a real pepper of distinction! Its nose takes you on a veritable plant journey which begins on a blend of full bodied notes of freshness and warmth. The journey continues on the taste buds with the finest of aromatic but the lightest of spicy hints. Wild pepper from Madagascar has no bite: an exquisite spice, full of finesse, it tickles the tongue artfully. We can't get enough of it!" Price: $197 € \mathrm{~kg}^{-1}$.

Spice Trekkers, http://spicetrekkers.com/ (accessed Mar. 23, 2016):

"A truly unique wild cubeb sourced from Madagascar. Its growing notoriety amongst Western chefs testifies to the incredibly aromatic profile of this pepper. Ready to take the world by storm. Like cubeb, black and long peppers, voatsiperifery is a true pepper. The woody and floral fragrance of these dense red-brown peppercorns evokes citrus. It has been called upon in Madagascar's culinary culture for centuries and is ideal for seasoning fish and seafood recipes. Its subtle sweetness and moderate heat are great for desserts and chocolate. For a great red meat seasoning, blend voatsiperifery pepper with other varieties. At one time this was an extremely rare spice. But it is gradually becoming a staple spice for adventurous and inventive cooks."

Price: 250 US\$ kg-1.

Sous Chef, http://www.souschef.co.uk/ (accessed Feb. 22, 2016):

"Voatsiperifery is an incredibly rare pepper with a strong, pine forest nose, and medium heat - distinguished by light, zesty flavours.

Voatsiperifery pepper grows in the hot and humid South-Eastern Madagascan rainforests, where the pepper vines can reach $20 \mathrm{~m}$ tall, and only grow in the wild, making picking very difficult.

The unripe berries are all hand-harvested by local village communities, and left to dry in the sun which turns the berries black [...].

Voatsiperifery is a beautiful pepper - and a great to lift any dish, whether meat or fish, particularly rich oily fish, or pork. The pepper is also good in sweet dishes, whether sprinkled over a fruit salad, or used to cut through the richness of a chocolate cake."

Price: 100 to $133 £ \mathrm{~kg}^{-1}$.

TABLE 2. Uses of tsiperifery by Malagasy people: results of an enquiry amongst 101 pickers (in the areas surrounding Anjozorobe, Ankaï and Fianarantsoa), 27 collectors and 11 exporters located in Antananarivo and Toamasina). Only the most frequent replies, reported at least five times, were taken into account (adapted from Razafimandimby [2011]).

\begin{tabular}{|c|c|c|c|}
\hline Usages & Parts of plant used & Preparations & Uses \\
\hline \multirow[t]{2}{*}{ Culinary } & Fruits & $\begin{array}{l}\text { Paste of fresh crushed fruit } \\
\text { blended with oil }\end{array}$ & $\begin{array}{l}\text { - ingredient of sakay (chilli pepper) } \\
\text { - spice of ravitoto (traditional dish of crushed manioc leaves) } \\
\text { - curry substitute }\end{array}$ \\
\hline & & Whole or ground dried fruit & - spice for enhancing meats, sausages and fish \\
\hline \multirow[t]{5}{*}{ Pharmacopoeia } & Leaves & Ground & - poultice for wound healing \\
\hline & Fruits & Whole or crushed & - antitussive, bronchial infections \\
\hline & & Ground only & - for treating male sexual disorders (generic use for sakay) \\
\hline & Stems & Infusion of stems & $\begin{array}{l}\text { - used externally for gangrene, scabies and skin lesions } \\
\text { - for post-natal infections }\end{array}$ \\
\hline & & Herbal tea & $\begin{array}{l}\text { - for treating venomous animal bites } \\
\text { - restoring liver function }\end{array}$ \\
\hline \multirow[t]{3}{*}{ Esoteric } & Leaves & Ground leaves & - wards off lightning strikes provoked by an ombiasy (sorcerer) \\
\hline & Stems and roots & Herbal tea & - ingredients for potions and ointments against magical spells \\
\hline & Leaves & Leaf thrown in the air & - prevents rainfall \\
\hline
\end{tabular}




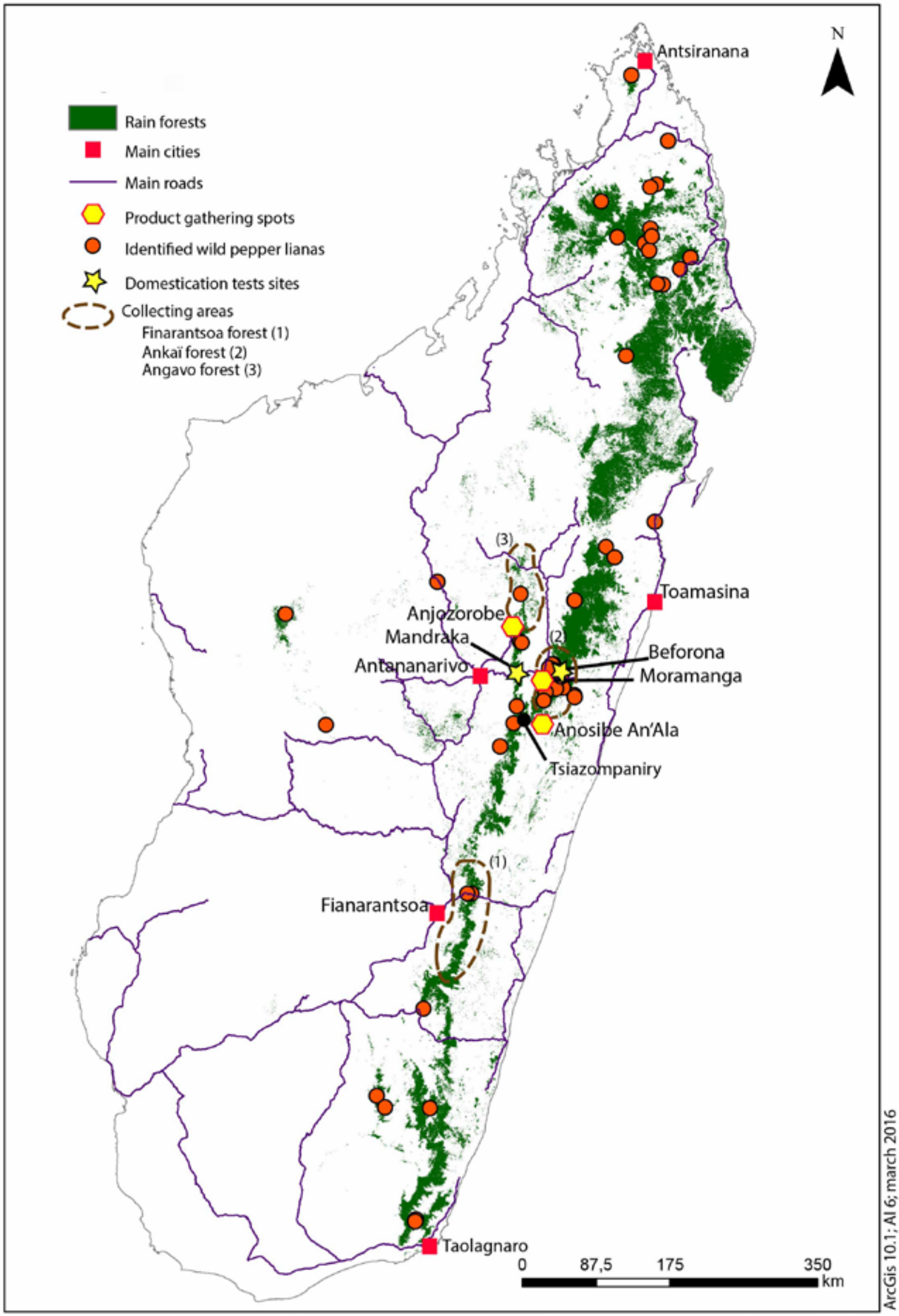

Coordinate system: GCS Tananarive Laborde 1925 Sources: FTM, vegmad, topicos.org, rebioma.net, TEF, TAN

FIGURE 1. Mapping trial of the sites where tsiperifery was present, and the gathering spots and sampling points of specimens referenced in the herbaria (TEF and TAN) of Madagascar. 
It is sold on local markets (small markets neighbouring the forests), medium-sized markets (in the towns located near the collection points) and regional markets (in Antananarivo and Fianarantsoa).

\section{A wild liana of the rainforest}

Whilst certain information regarding the plant, its biology and its ecology is available, there is still a lot of basic knowledge lacking. Currently, information as basic as the boundaries of tsiperifery's distribution is not completely fixed. Figure 1 is an attempt to synthesize current knowledge on its distribution, based essentially on the word of the collectors and the collection points of specimens deposited in Madagascar's two national herbaria (TEF of the Centre National de Recherches Appliquées au Développement Rural, and TAN of the Parc Botanique et Zoologique de Tsimbazaza). It shows that tsiperifery can be found in the majority of the evergreen forests in eastern Madagascar right from Antsiranana at the northern tip down to Taolagnaro in the south.

The plant is a liana, which climbs up to 10 to 12 metres on a support, generally large trees (Figure 2a). It appears that certain species of tree take prevalence over others as supports Peponidium buxifolium, Bremeria trichophlebia, Dichaethantera arborea, Cryptocarya spp., Ocotea spp., Syzygium spp. (Razafimandimby, 2011). The liana climbs up the support attaching itself by roots which are produced at the nodes (Figure $2 b$ ). The leaves are simple and alternate. Leaf dimorphism can be seen to occur in the same plant. The or- thotropic stems growing from the collar bear cordate leaves (Figure 2c) whilst the plagiotropic branches in the crown have elliptical to oblong shaped leaves (Figure 2d). The plant is dioecious. Male and female inflorescences are composed of solitary spikes opposite the leaf (Figures 2e-f). Its fruits consist of small berries ranging in color at maturity from red to orange (Figure $2 \mathrm{~g}$ ). These berries retain their pedicels, which detach themselves from the stalk on drying (like the cubeb). This explains why they are sometimes referred to as 'tailed pepper of Madagascar'. They flower annually. Optimal fruiting time is between October and December.

These botanical elements confirm that tsiperifery belongs to the Piper genus (Piperaceae family). This genus contains more than 2,000 known species throughout the world (Quijano-Abril et al., 2006; Jaramillo et al., 2008), less than 600 of which have been described (Jaramillo and Manos, 2001). However, the taxonomic classification of tsiperifery is unclear. The last valid revision of the classification of the Malagasy peppers established by De Candolle in 1923 (De Candolle, 1923; Decary, 1946) divides tsiperifery into three species: Piper borbonense C.DC, Piper pyrifolium Vahl, and Piper pachyphyllum Baker. In 1946, Decary (1946) named Piper borbonense, what produces "a sort of cubeb pepper" amongst Madagascar's stimulant plants. Manjato et al. (2010) produced a new classification in 2010 which remains provisional and unpublished, identifying thirteen species of Piper in Madagascar including P. pachyphyllum, P. borbonense, $P$. heimii, and four new endemic species, which may
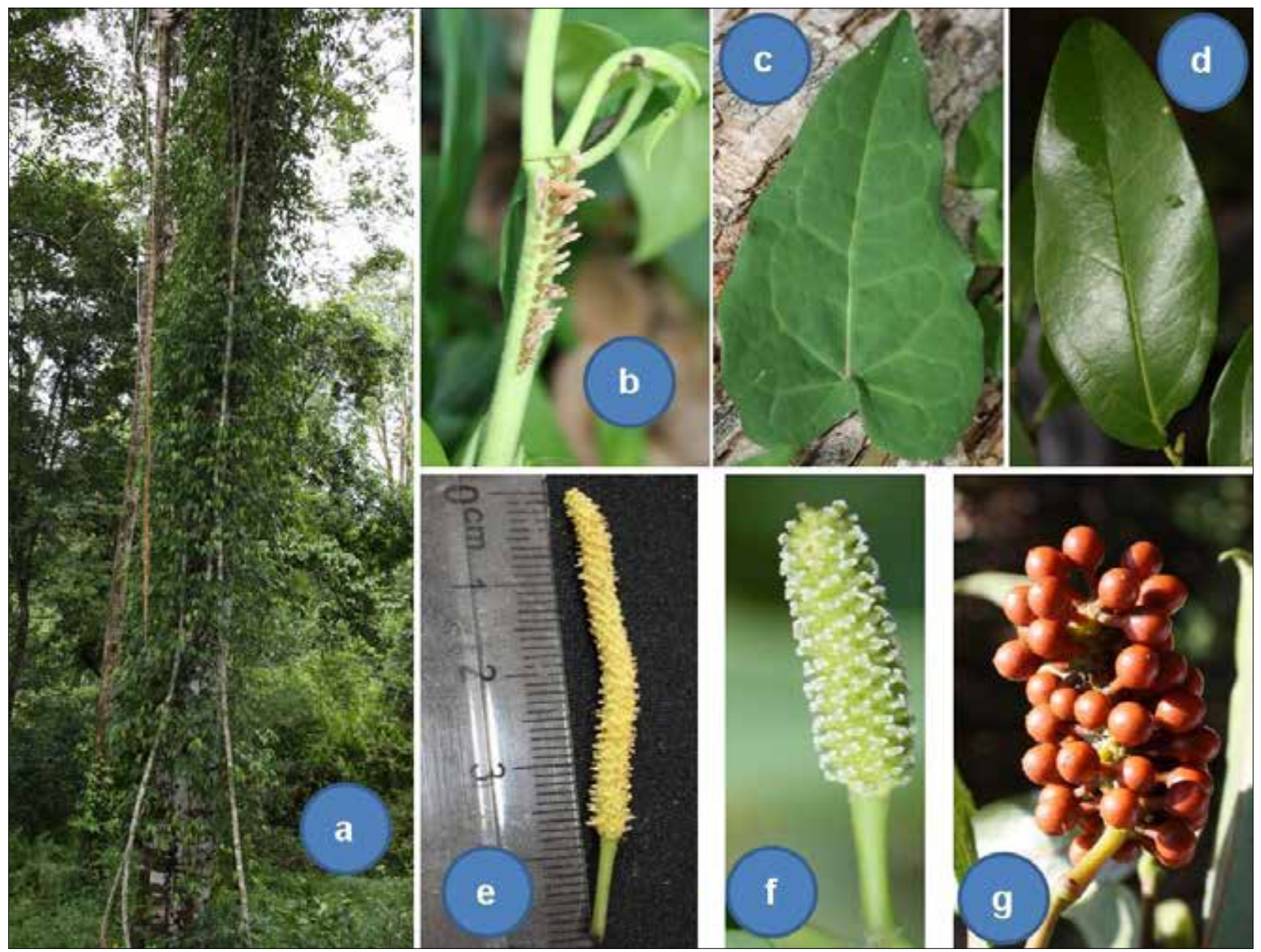

FIGURE 2. Botanical elements: a) tsiperifery on its support; b) clinging roots; c) cordate leaves; d) elliptical leaves; e) male inflorescence; f) female inflorescence; g) mature bunch of fruit (Photos by Razafimandimby). 


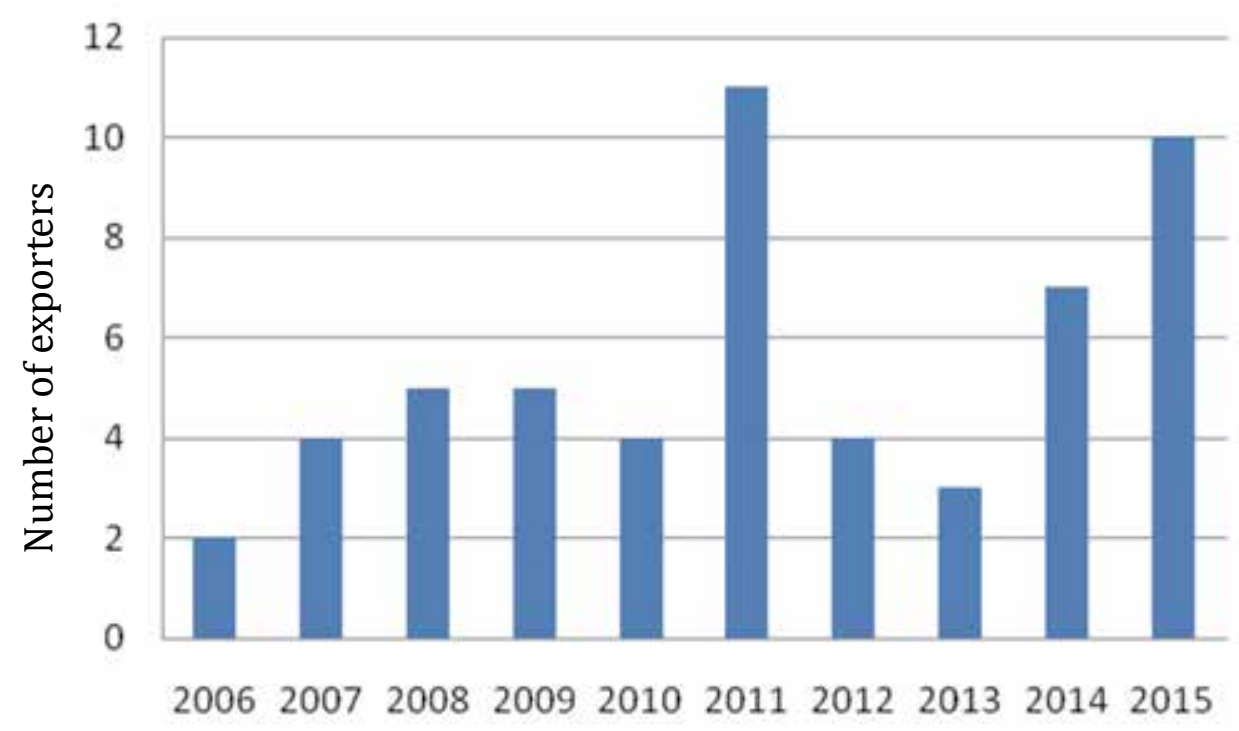

\section{Years}

FIGURE 3. Progression in the number of exporters of tsiperifery supplied by the catchment area of Anjozorobe-Angavo from 2006 to 2015.

correspond to descriptions of tsiperifery. It is obvious from these infrageneric classification studies of the Piper genus in Madagascar that "tsiperifery" as a generic denomination very likely applies to more than one species.

Studies using the tools of molecular biology are in progress to clarify this information and provide answers as to: whether the variations observed represent infrageneric or infraspecific diversity; whether tsiperifery are really endemic to Madagascar; what the genetic association of tsiperifery is with $P$. borbonense from Reunion Island; what the relationship is between genetic diversity and organoleptic quality, and whether there is a potential in genetic selection for improving the quality of products, offering prospects for domestication of tsiperifery.

\section{A recent and systematic operation}

Local entrepreneurs and exporters promptly identified the economic potential of tsiperifery and snapped it up. Since its inception in 2004, the export sector has been rapidly developing. In one of the oldest picking catchments, at Anjozorobe-Angavo, the number of handlers has risen from two in 2006 to around ten at present, varying widely from one year to another (Figure 3). Added to these local businesses, a number of foreign companies have developed their own sectors, trading nonetheless in what seems to be low volumes (Touati, 2012).

Touati (2012) estimated around $50 \mathrm{t}$ the total exports of tsiperifery (dry peppercorns) in 2011. In 2014, an estimated weight of $25 \mathrm{t}$ was exported. These figures need to be treated with caution, as they are estimates provided by the sector participants. Since wild pepper is at present unregulated, it is presently exported as black pepper and therefore not referenced under Madagascar's exports (Raharijaona, 2015). However, these figures give a rough idea of the quantities exported, which show that the trade in tsiperifery addresses a niche market compared with other spices exported by Madagascar, such as cloves and vanilla (Danthu et al., 2014).
It seems nevertheless that picking exceeded the natural production capacity of the first areas exploited. As a consequence, handlers have extended their collecting areas and opened up new supply catchments. The exported peppercorns still come mainly from two areas: the natural forests of Angavo (worked since 2006) and Ankaï (worked since 2009) (Figure 1). An operation began in the Fianarantsoa corridor in 2009 (Figure 1) but it appeared to have ceased in 2012 (Touati, 2012).

Within these collecting areas, and external to the local traditional market, the tsiperifery operation is organized as a supply chain with four levels at most (Figure 4). The tsiperifery operation still seems to be driven predominantly by a logic of short term gain and maximum profit.

The pickers are the first link in the supply chain. They are local peasant farmers with meagre earnings, who live in or bordering on the forest, and subsist on food crops, supplemented by what they can earn from collecting nontimber forest products such as honey and pepper. At the beginning of the picking season, the pickers are approached by the handlers, the second link in the chain.

These handlers are not specialised; they act as intermediaries and deal in a wide diversity of local products (chilli peppers, guavas, ginger...) selling them on to exporters and national distributors located in the urban centres (mainly in Antananarivo and Toamasina), who make up the third level in the supply chain. The produce is then sold in retail shops across the island and exported on the international market.

The handlers manage the operations of sorting, drying, storing and transporting the fruits. It is rare that they deliver fresh tsiperifery to their clients because of the increasing remoteness of the growing zones and because drying and then transporting the dry peppercorns improves the operation's profitability. Indeed, dry batches do not rot, are cheaper to transport, sell for more and are easier to keep. Some even use their storage facility to speculative ends. 


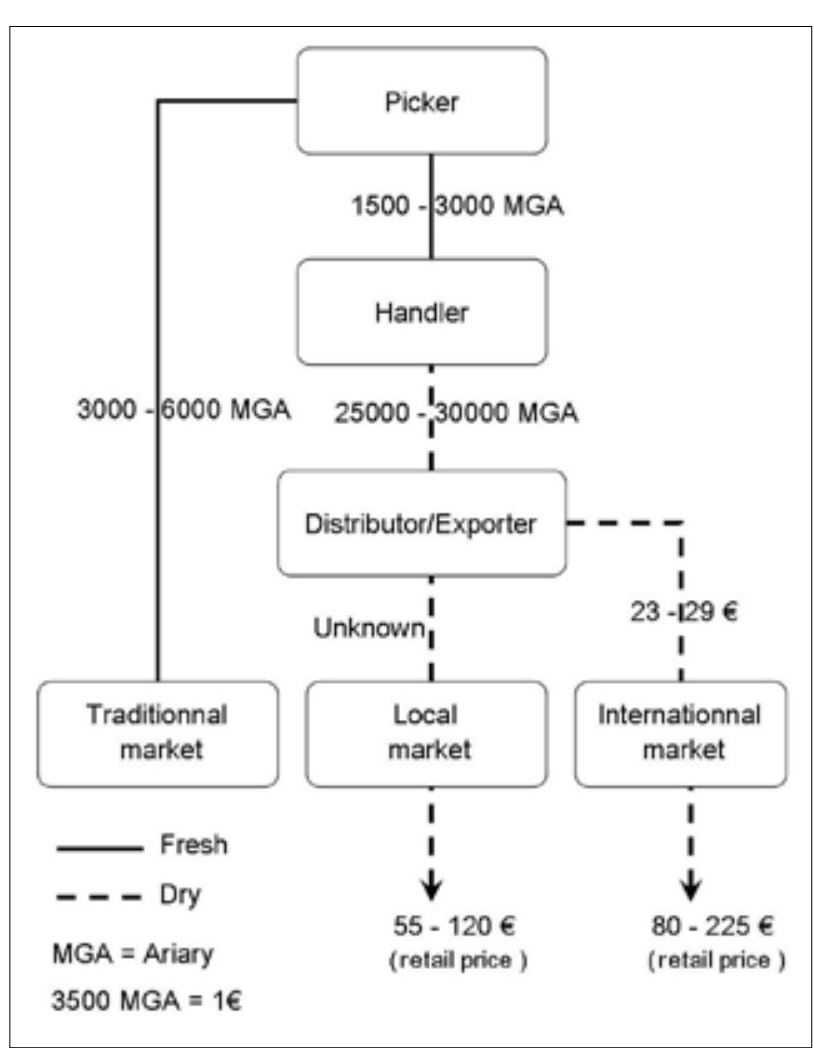

FiguRE 4. Structure of the sector and retail price scale (Ariary $\mathrm{kg}^{-1}$ ) for fresh and dry tsiperifery in the picking catchment of Angavo forest in 2015.

There are no contractual relationships between pickers, handlers and exporters. At each level of the sector, batches can be sold to a higher bidder, not to mention an opportunistic buyer. The lack of structure in the sector limits the possibilities for technical support, which might result in improvements to the technical, environmental and social qualities of the product.

There is an extreme inequity in the distribution of added value between participants in the wild pepper supply chain (Figure 4). It apportions the smallest earnings to the poorest located at the upper reaches of the operation and generates more profit for those downstream. The picker sells $1 \mathrm{~kg}$ fresh peppercorns to the handler for 3,000 Ariary (MGA) (0.80€). Considering the fresh berries contain $80 \%$ moisture, this amount is roughly equivalent to 15,000 MGA (4 €) per kilo of dry tsiperifery (Figure 4). Dry tsiperifery in Europe and the USA can sell for anything up to and above $200 € \mathrm{~kg}^{-1}$ in delicatessens and online (Table 1; Figure 4). Consequently, the picker receives $2 \%$ of the product's final value. Whilst this is a rough calculation, it shows that the operators upstream in the wild pepper sector come off very badly compared with other export operations, such as the clove sector, in which the producer receives up to $15 \%$ of the product's final value: the producer is paid $20,000 \mathrm{MGA} \mathrm{kg}^{-1}$ cloves, equivalent to $5.70 €$, and it is sold $<100 € \mathrm{~kg}^{-1}$ on the European wholesale market (Danthu et al., 2014; Demangel, 2011).

The authors believe that the impact of uncontrolled expansion in the sector on a badly identified resource about which neither the availability nor the biology is known needs to be assessed. Similarly, the impact on the biological resource, but also the distribution of earnings between the different participants should be ascertained.

\section{A resource faced with multiple threats}

\section{Environmental risks associated with destructive picking practices}

Previously tsiperifery would have been picked at an opportune time whilst out in the forest for other activities (hunting, collecting other produce), but now it is collected systematically. This excessive strain is aggravated by a destructive method of picking, which consists in ripping away the fruiting creeper from its host and even cutting the support along with the liana to access the berries. This picking method leads to the rarefaction of female rootstock in the growing zones. Whilst it endangers the resource itself, it also harms the forest ecosystems and exhausts the picking catchment area in the short-term.

Moreover, the abundance of tsiperifery vines is viewed by the locals as an indication of soil fertility and as such a sign that the soil is right for slash and burn (tavy in Malagasy, a widespread agricultural practice in the eastern forestry corridor [Aubert et al., 2003]). Consequently, it is not unusual to see an area richly supplied in tsiperifery either stripped bare or transformed into paddy field (Levesque, 2012). Timber poaching further encourages new openings in the canopy, thus depriving wild pepper vines of both potential hosts (Touati, 2012; Razafimandimby, 2011), as well as the shade essential for the growth of the vine, resulting in the destruction of their ecosystem to which they are very sensitive (Razafimandimby, 2011).

On this basis stands the difficult issue of balancing the preservation of the ecosystems and a sustainable exploitation of tsiperifery.

\section{Variations in the product quality, a threat to the reputation of tsiperifery}

The organoleptic quality of tsiperifery is considered very unreliable by those involved in the operation, notably exporters and retailers, but also consumers, when questioned. This irregularity and sometimes mediocrity in the quality could in the long run damage the reputation of tsiperifery, deterring buyers and impacting on the incomes of the sector's different operators.

Handlers and exporters point the finger at postharvest treatments and irregularities in the maturity of the picked berries as a reason for this decline in quality, what has been validated by Weil et al. (2014). However, there might be other factors such as genetic variability and the environment (climate, terroir, soil, phyto-sociology) behind this variability. Handlers and exporters also complain about the instability of supply connected to unreliable provision. Quantities collected vary substantially throughout the year, and from one year to the next. Some operators explain this irregularity by the inter-annual variation in production of lianas and others put it down to resource rarefaction. The latter argument is supported by the fact that pickers have to trek further and further into the forest, each year, to find new fruiting vines. The foraging expedition that used to take one hour now takes more than six, and in order to ensure a good crop, some pickers in certain zones now spend four to seven days camping out in the forest to reach areas suspected to be well-supplied with lianas.

One field of knowledge, just opened up by Weil et al. (2014), raises questions about the quality of the products. The impact of postharvest treatments and the irregularity in the maturity of the berries on the quality of tsiperifery vines 
remain to be explored, as well as the influences of biological determinants (genetic and morphological diversity) and the ecological conditions for expressing the organoleptic quality.

\section{Research implicated in the development of a sustainable sector}

At the present time, a context combining significant uncertainty and urgency hangs over tsiperifery exploitation in Madagascar. Information and data collected to date lead us to conclude that the various stakeholders in the sector, pickers, handlers, economic operators and public authorities operate without reliable knowledge of the plant ecology, the extent of real stock, the sustainable level of picking, the different picking practices, or the impact of treatments on the quality of the product and the durability of the sector. This lack of knowledge and the absence of some form of coordination in the sector are two limiting factors. A companion research project may go some way to addressing these factors. Reducing uncertainties about the biology of the plant, its exploitation and transformation may improve the relevancy of stakeholders' decisions and actions.

However, at its current rate of degradation, the resource cannot wait for scientific knowledge to be fully conclusive before the process of circulating innovations is implemented. It seems imperative to accelerate the innovation process by grounding the research on tsiperifery in a combined partnership between scientists, economic operators, administrative bodies and local communities. Adopting the so-called paradigm of post-normal science (Funtowicz and Ravetz, 1993) would enable the delay in knowledge production to be bridged. A consultative participatory approach in which researchers collaborate with all stakeholders should bring about an improvement in efficiency of the innovation process (Joly and Lemarié, 2000) and simultaneously accompany the emergence of sustainable adaptive governance (Dietz et al., 2003) in the tsiperifery sector.

The proposed strategy takes its inspiration from Douthwaite et al. (2001) 'Follow the Technology' concept. It consists of relaying to local communities and economic operators credible technical solutions which, whilst not completely finalised, offer 'plausible promises' of success. Follow-up and evaluation of adoption, refusal or adaptation of these technical solutions will feed into the recurring innovation process. Preliminary results currently in the pipeline will allow the authors to consider implementing the concept at a local level at several sites and in two complementary and connected spheres: (i) development of a 'label' of quality and origin of tsiperifery, and (ii) a process of domestication drawn from a pool of selected plant matter.

We are currently working on these two major areas of research within various projects funded by (or accountable to) different financing bodies: the European Union through projects supported by the European Development Fund (EDF), the French Ministry of Foreign Affairs and International Development (PISCCA fund for civil society: 'Innovative projects from Civil Societies and Coalitions of Actors'). Whilst these projects involve research, implicating particularly the present authors' collective, they also require the actors in the supply chain to join forces, specifically those downstream (entrepreneurs/exporters). The priority in these projects is to improve the competitiveness, organization, sustainability, ethics and reputation of the sector, with specific reference to the upstream element (pickers/collectors).

\section{A process for creating a 'label' of quality and origin,}

\section{the basis for sustainable management}

Wild pepper from Madagascar ranks highly amongst the premium quality, niche market spices (Couplan, 2009; Vives, 2010). The reputation it enjoys on the international market is based on its organoleptic qualities, its unique origin and rarity. Distributors and exporters thus tap into the exoticism of Madagascar.

The boom in international demand for 'quality' products whose origin is known to the consumer coincides with the emergence of societal concerns such as environmental conservation, fair trade and enhancement of cultural heritage. Developing a recognized seal of quality may therefore contribute to the sustainability of tsiperifery pepper. Obtaining a quality label is a voluntary procedure carried out by a group to promote a product by highlighting a distinctive comparative advantage. The reason for this distinction may be in the production, processing or marketing of the product. There are many different types of voluntary quality labels for food products. Amongst those which are well-known to European consumers are, for example, the labels of origin such as protected geographical indication (PGI), and protected designation of origin (PDO), the various national and European organic farming logos and the Fairtrade certification. According to Amsallem (2010), Gloanec and Porphyre (2012), and Barjolle et al. (2013), the certification of quality associated with origin brings benefits in three spheres: environmental, social and economic.

Pepper from Penja (Cameroon), white honey from Oku (Cameroon) as well as coffee from Ziama (Guinea), were the first officially protected geographical indications (PGI) in Africa. This approach appears to be conducive to improving market opportunities and increasing incomes for the different participants in local operations, including the pickers (AFD, 2014). Such an approach may also benefit tsiperifery from Madagascar.

The implementation process of a geographical indication is well established and, as applied to tsiperifery, would consist in the following stages (AFD, 2014):

(i) define the intrinsic qualities of tsiperifery;

(ii) define and clarify the factors determining these qualities (means of harvesting, postharvest treatments, etc.);

(iii) draft detailed technical specifications (plant management, good picking practices, processing and preserving related regulations, etc.);

(iv) delineate favorable production areas;

(v) identify all concerned value-chain stakeholders (pickers, handlers, exporters); and

(vi) apply to the bodies responsible for granting and regulating the label.

However, there are potential obstacles inherent in the process, such as the fact that Madagascar is not a member of the OAPI (Organisation Africaine de la Propriété Intellectuelle) which registered the first PGI mentioned above. Furthermore, providing for a geographical indication process in developing countries requires certain key issues to be addressed, starting with a system to achieve dialogue and negotiation among stakeholders (Cormier-Salem and Roussel, 2009; François et al., 2009). A set of specifications must then be determined ('code of practice') that would explicitly link sustainable production and processing methods with the acquisition of anticipated qualities (intrinsic and extrinsic) of the local produce (Cormier-Salem and Roussel, 2009). 
The stakeholders in the operation would further be required to organize themselves in such a way as to support and make a concerted commitment to their product (François et al., 2009).

With regard to tsiperifery wild pepper, the entire process would currently be difficult to accomplish. Some prerequisites are lacking, such as the official PGI registration process in Madagascar, as well as quality characterization and delimitation of the production zone, all of which depend on further research. However, some promising assets are present. Firstly, the operation relies on the involvement of a very small number of players. The product is highly profitable for pickers, processors and traders. Research is already actively participating. Some developments could therefore be envisaged through a process of capacity building (AFD, 2014). From this perspective, the first stage could be to back the creation of a collective body of tsiperifery pickers.

\section{Domestication for sustainable management}

The second field of action research that the collective proposes to open up is the domestication of tsiperifery (Ceuppens, 2014). This would ensure fruit production which is both stable and easy to manage in quality and quantity, and reduce the rate of picking from the natural environment. In the long run, domestication enables a process of improvement in the intrinsic quality of the plant and the produce.

However, the domestication of a forest species is a complex procedure (Simons and Leakey, 2004). Where tsiperifery is concerned, it requires interdisciplinary research to be applied to different aspects of the activity: (i) geneticist, quality experts, chemists and biologists to define and select a superior quality plant material; (ii) agronomists and ecologists to improve propagation methods; (iii) technologists and agronomists to ensure the proficiency in the product's transformation; and (iv) sociologists and economists to highlight different ways of developing and organising a domestic tsiperifery operation.

This domestication would bring about positive outcomes for local populations as shown by Leakey et al. (2005): decline in poverty, improvements in household income of pickers, food security, reduced pressures on the ecosystem. An added important consideration is that it will also bring about a reconfiguration in the social and spatial production activities. The involvement of local stakeholders early on in the innovation process should makes it possible to anticipate these changes and preserve a degree of equity in the share of the profits of this domestication.

\section{Advocacy for involving all players of the tsiperifery sector}

There are some very old, well documented examples of poorly thought out exploitation of Madagascar's non-timber forestry products such as natural rubber (from forest species such as Euphorbia intisy) in the early 19th century (Danthu et al., 2016), and more recently Prunus africana (BIODEV, 1999; Stewart, 2003; Jimu, 2011). They resulted in a weakening of the resource such that the plant species in question have been classified in the CITES appendix II (CITES, 2016), which implies that trading them is subject to official approval and quotas. These sectors consequently slumped and the products now traded in their place are substitutes. It can only be assumed from the dynamics observed combined with a lack of a sustainable management strategy for the resource and its valorization context and control (CITES, 2016) that tsiperifery is heading in the same direction.
In the face of these observations and in order to establish the bases for sustainable exploitation of wild pepper in Madagascar, whilst ensuring the conservation of the ecosystems and fair earnings for all the operators, research would be organised around three axes: (i) improve knowledge of the plant's biology, particularly its genetic diversity, the delimitation of its distribution area, the evaluation of its total stock and the characterisation of the transformation procedures used to optimise the quality of its products; (ii) develop technical itineraries for domestication, by exploring ecological and social effects of different domestication strategies; (iii) support the coordination of the sector via a process of co-construction of a collective 'label' involving all the stakeholders. Considering the urgency and fragility of the situation, a strategy involving scientists, economic operators, authorities and local communities is proposed in order to test, evaluate and rapidly transfer (or not) the innovations.

However, such an approach can only be effective if backed by a sustained political and economic commitment to support the project. Without proactive support from government authorities, professional stakeholders and international organisations, tsiperifery could rapidly join the ranks of Euphorbia intisy, Prunus africana, and the Malagasy rosewoods in the CITES Appendix ll.

\section{Acknowledgments}

This study was carried out by the DP 'Forêts et Biodiversité, a partnership between FOFIFA, the University of Antananarivo and CIRAD. It was supported by 'France Volontaires'. The authors would like to thank the FSP 'Parrur' (project 'InnovEpice') funded by the French Ministry of Foreign Affairs and International Development, the QualiReg network, and CIRAD which funded this study. The association 'Words for Solidarity' is gratefully acknowledged for the translation.

\section{References}

AFD (Agence Française de Développement) (2014). L'AFD et les indications géographiques protégées - valoriser les savoir-faire et accroître les revenus des producteurs (Paris, France: AFD), 4 pp.

Amsallem, I. (2010). Indications géographiques: qualité des produits, environnement et cultures, Savoirs Communs 9 (Agence Française de Développement et Fonds Français pour l'Environnement Mondial).

Aubert, S., Razafiarison, S., and Bertrand, A. (eds.) (2003). Déforestation et systèmes agraires à Madagascar - Les dynamiques des tavy sur la côte orientale (Montpellier, France: Cirad/Cite/Fofifa).

Barjolle, D., Renard, O., and Bernardoni, P. (2013). Etude du potentiel de la commercialisation des produits agricoles des pays ACP (Afrique, Caraïbes, Pacifique) utilisant des indications géographiques et des marques avec origine (Lausanne, Switserland: REDD SA).

BIODEV (1999). Etude de la filière flore sauvage: Pygeum africanum. Rapport final (Antananarivo, Madagascar: Unité de Coordination du PEII/Forêt, Ministère des Eaux et Forêts), 71 pp.

Ceuppens, Q. (2014). Madagascar wild pepper at risk. http://www. agriculture-biodiversité-oi.org/en/Nature-agriculture/New-fromthe-field/Articles (accessed Apr. 1, 2016).

CITES (Convention on International Trade in Endangered Species of Wild Fauna and Flora) (2016). Appendices I, II and III. https://cites. org/fra/app/appendices.php (accessed Mar. 20, 2016).

Cormier-Salem, M.C., and Roussel, B. (2009). Localiser les produits et valoriser les spécialités locales - Une dynamique générale et foisonnante, Autre part 50, 3-15. https://doi.org/10.3917/ autr.050.0003. 
Couplan, F. (2009). Le régal végétal - Plantes sauvages comestibles (Paris, France: Editions Sangs de la Terre).

Danthu, P., Penot, E., Ranoarisoa, K.M., Rakotondravelo, J.C., Michel, I., Tiollier, M., Michels, T., Normand, F., Razafimamonjison, G., Fawbush, F., and Jahiel, M. (2014). The clove tree of Madagascar, a success story with an unpredictable future. Bois For. Trop. 320, 83-96.

Danthu, P., Razakamanarivo, H., Deville-Danthu, B., Razafy Fara, L., Le Roux, Y., and Penot, E. (2016). The brief and forgotten history of forest rubber in Madagascar, yet first subject of controversy between biodiversity conservation and natural resource exploitation. Bois For. Trop. 328, 27-43.

De Candolle, C. (1923) Piperacearum clavis analytica. Candollea 1, 65-415. https://doi.org/10.5962/bhl.title.15548.

Decary, R. (1946). Plantes utiles de la flore malgache. Rev. Int. Bot. App. Agric. Trop. 26, 383-389. https://doi.org/10.3406/ jatba.1946.1979.

Demangel, A. (2011). Faisabilité de la mise en place d'une indication géographique sur le clou de girofle à Madagascar. (Cergy-Pontoise, France: Ecole supérieure d'Agro-Développement International [ISTOM]). Mémoire de fin d'étude, 103 pp.

Dietz, T., Ostrom, E., and Stern, P. (2003). The struggle to govern the commons. Science 302, 1907-1912. https://doi.org/10.1126/ science.1091015.

Douthwaite, B., de Haan, N.C., Manyong, V., and Keatinge, D. (2001). Blending "Hard" and "Soft" science: the "Follow-the-Technology" approach to catalyzing and evaluating technology change. Ecol. and Soc. 5 (accessed Mar. 21, 2016).

François, M, Seyrevath, P., and Brun, J.M. (2009). Indication géographiques au Cambodge - Protéger les marques de territoire au profit des producteurs ruraux. Autre part 50, 75-91. https://doi. org/10.3917/autr.050.0075.

Funtowicz, S.O., and Ravetz, J.R. (1993). Science for the postnormal age. Futures 25, 739-755. https://doi.org/10.1016/00163287(93)90022-L.

Gloanec, C., and Porphyre, V. (2012). Les démarches de qualité en Océan Indien: quelles réponses face aux enjeux des filières agroalimentaires de l'Océan Indien? (Saint Pierre de La Réunion, France: Réseau QualiREG).

Jaramillo, M.A., Callejas, R., Davidson, C., Smith, J.F., Stevens, A.C., and Tepe, E.J. (2008). A phylogeny of the tropical genus Piper using ITS and the chloroplast intron psbJ-petA. Syst. Bot. 33, 647-660. https:// doi.org/10.1600/036364408786500244.

Jaramillo, M.A., and Manos, P.S. (2001). Phylogeny and patterns of floral diversity in the genus Piper (Piperaceae). Am. J. Bot. 88, 706716. https://doi.org/10.2307/2657072.

Jimu, L. (2011). Threats and conservation strategies for the African cherry (Prunus africana) in its natural range - A review. J. Ecol. Nat. Environ. 3, 118-130.

Joly, P.B., and Lemarié, S. (2000). Cinquante ans d'innovation en agriculture - Quelques enseignements des approches socioéconomiques. Econ. Rur. 255, 86-97. https://doi.org/10.3406/ ecoru.2000.5159.

Leakey, R.R.B., Tchoundjeu, Z., Schreckenberg, K., Shackleton, S.E., and Shackleton, C.M. (2005). Agroforestry tree products (AFTPs): targeting poverty reduction and enhanced livelihoods. Int. J. Agr. Sustain. 3, 1-23. https://doi.org/10.1080/14735903.2005.9684741.

Levesque, A. (2012). Etude de différents schémas de vie mis en œuvre sur le Tsiperifery-poivre sauvage malgache (La Réunion, France : CIRAD et SupAgro). Mémoire de césure, 98 pp.
Manjato, N., Ramahefaharivelo, A., Davidson, C., and Phillipson, P. (2010). The Malagasy species of Piper (Piperaceae). Scr. Bot. Belg. $46,284$.

Phillips, O., and Gentry, A.H. (1993). The useful plants of Tambopata, Peru: I. Statistical hypotheses tests with a new quantitative technique. Econ. Bot. 47, 15-32. https://doi.org/10.1007/BF02862203.

Quijano-Abril, M.A., Callejas-Posada, R., and Miranda-Esquivel, D.R. (2006). Areas of endemism and distribution patterns for neotropical Piper species (Piperaceae). J. Biogeogr. 33, 1266-1278. https://doi. org/10.1111/j.1365-2699.2006.01501.x.

Raharijaona, A.S. (2015). L'importance de l'identification juridique des participants à la gestion durable du tsiperifery: cas d'Anjozorobe (Antananarivo, Madagascar: Université d'Antananarivo). Mémoire de Master, $144 \mathrm{p}$.

Ratsaraefatrarivo, M.H.T. (2012). Etude de variabilité spécifique $\mathrm{du}$ poivre sauvage ou voatsiperifery, Piper sp. (tsiperifery) dans les versants ouest et est du corridor Anjozorobe-Angavo et détermination des paramètres de qualité (Antananarivo, Madagascar: Ecole Normale Supérieure, Université d'Antananarivo). Mémoire de Certificat d'Aptitude Pédagogique de l'Ecole Normale, 76 pp.

Razafimandimby, H. (2011). Etudes écologique et ethnobotanique de Tsiperifery (Piper sp.) de la forêt de Tsiazompaniry pour une gestion durable (Antananarivo, Madagascar: Université d'Antananarivo). Mémoire de Diplôme d'Etudes Approfondies, 48 pp.

Simons, A.J., and Leakey, R.R.B. (2004). Tree domestication in tropical agroforestry. Agroforest. Syst. 61, 167-181. https://doi. org/10.1023/B:AGF0.0000028997.74147.f9.

Stewart, K.M. (2003). The African cherry (Prunus africana): can lessons be learned from an over-exploited medicinal tree? J. Ethnopharmacol. 89, 3-13. https://doi.org/10.1016/j. jep.2003.08.002.

Touati, G. (2012). Etat des lieux de la filière du poivre sauvage de Madagascar - Un produit forestier non ligneux exploité pour la commercialisation (Cergy-Pontoise, France: Ecole supérieure d'Agro-Développement International [ISTOM]). Mémoire de fin d'étude, $78 \mathrm{pp}$.

Vives, G. (2010). Poivres (Rodez, France: Editions du Rouergue).

Weil, M., Descroix, F., Shum Cheong Sing, A., Boulanger, R., Hoarau, M., Levesque, A., and Bohuon, P. (2014). Postharvest treatments of wild pepper (Piper spp.) in Madagascar. Fruits 68, 371-380. https://doi. org/10.1051/fruits/2014025.

Received: Jul. 26, 2016

Accepted: Nov. 23, 2016 